OPEN ACCESS

Edited by:

Micaela Fredi

University of Brescia, Italy

Reviewed by:

Veronica Codullo,

Hôpital Cochin, France

Motohisa Yamamoto,

University of Tokyo, Japan

Ariela Hoxha,

San Bortolo Hospital, Italy

*Correspondence:

Pietro Enea Lazzerin

lazzerini7@unisi.it

†These authors have contributed equally to this work

${ }^{\ddagger}$ Retired

Specialty section: This article was submitted to Rheumatology,

a section of the journal

Frontiers in Medicine

Received: 24 June 2021 Accepted: 11 August 2021

Published: 06 September 2021

Citation

Lazzerini PE, Laghi-Pasini F Boutjdir M and Capecchi PL (2021) Anti-Ro/SSA Antibodies and the Autoimmune Long-QT Syndrome.

Front. Med. 8:730161 doi: 10.3389/fmed.2021.730161

\section{Anti-Ro/SSA Antibodies and the Autoimmune Long-QT Syndrome}

\author{
Pietro Enea Lazzerini ${ }^{1 *}$, Franco Laghi-Pasini ${ }^{1+\neq}$, Mohamed Boutjdir ${ }^{2,3+}$ and \\ Pier Leopoldo Capecchi ${ }^{1+}$
}

${ }^{1}$ Department of Medical Sciences, Surgery and Neurosciences, University of Siena, Siena, Italy, ${ }^{2}$ Veterans Affairs New York Harbor Healthcare System, State University of New York Downstate Medical Center, New York, NY, United States, ${ }^{3}$ New York University School of Medicine, New York, NY, United States

Autoimmunity is increasingly recognized as a novel pathogenic mechanism for cardiac arrhythmias. Several arrhythmogenic autoantibodies have been identified, cross-reacting with different types of surface proteins critically involved in the cardiomyocyte electrophysiology, primarily ion channels (autoimmune cardiac channelopathies). Specifically, some of these autoantibodies can prolong the action potential duration leading to acquired long-QT syndrome (LQTS), a condition known to increase the risk of life-threatening ventricular arrhythmias, particularly Torsades de Pointes (TdP). The most investigated form of autoimmune LQTS is associated with the presence of circulating anti-Ro/SSA-antibodies, frequently found in patients with autoimmune diseases (AD), but also in a significant proportion of apparently healthy subjects of the general population. Accumulating evidence indicates that anti-Ro/SSA-antibodies can markedly delay the ventricular repolarization via a direct inhibitory cross-reaction with the extracellular pore region of the human-ether-a-go-go-related (hERG) potassium channel, resulting in a higher propensity for anti-Ro/SSA-positive subjects to develop LQTS and ventricular arrhythmias/TdP. Recent population data demonstrate that the risk of LQTS in subjects with circulating anti-Ro/SSA antibodies is significantly increased independent of a history of overt $A D$, intriguingly suggesting that these autoantibodies may silently contribute to a number of cases of ventricular arrhythmias and cardiac arrest in the general population. In this review, we highlight the current knowledge in this topic providing complementary basic, clinical and population health perspectives.

Keywords: anti-Ro/SSA antibodies, long QT syndrome, autoimmune cardiac channelopathies, hERG potassium channel, Torsades de Pointes, sudden cardiac death

\section{INTRODUCTION}

The long QT-syndrome (LQTS) is a cardiac electric disorder characterized by an abnormal prolongation of the heart rate-corrected QT interval (QTc) on the electrocardiogram (traditionally $>440 \mathrm{~ms}$; currently, $>470 \mathrm{~ms}$ for men, and $>480 \mathrm{~ms}$ for women) (1) which predisposes to life-threatening ventricular arrhythmias (VAs), specifically Torsades de Pointes (TdP) (1-3). TdP is a polymorphic ventricular tachycardia presenting with a typical pattern of 
twisting points that can rapidly degenerate into ventricular fibrillation (VF) and cause sudden cardiac death (SCD) (1). The more the QT prolongs the more the risk of $\mathrm{TdP}$ increases, it becoming high for QTc > $500 \mathrm{~ms}$, very high for QTc $>600 \mathrm{~ms}$ (1). In addition, accumulating evidence indicates that when QT interval prolongs as the result of the specific lengthening of the terminal component of the $\mathrm{T}$ wave, from the peak to its end (Tpeak-Tend interval, Tp-Te), the risk to develop TdP is particularly important $(4,5)$.

The QTc on the electrocardiogram (ECG) is commonly used in the clinical practice as a proxy of the average action potential duration (APD) in ventricular cardiomyocytes, in turn determined by the sequential activation of several ion channels mediating inward depolarizing (sodium, $\mathrm{Na}^{+}$and calcium, $\mathrm{Ca}^{++}$) or outward repolarizing (potassium, $\mathrm{K}^{+}$) currents, respectively (6). Whenever a dysfunction of one or more of these channels occurs leading to a net inward shift in the balance of currents (i.e., an increase of $\mathrm{Na}^{+}$or $\mathrm{Ca}^{++}$ currents and/or a decrease of $\mathrm{K}^{+}$currents), APD prolongs and, therefore, the QTc $(6,7)$. A wide number of etiologic factors can be responsible for LQTS, classically categorized as congenital, due to mutations in genes encoding for $\mathrm{K}^{+}$, $\mathrm{Na}^{+}$, or $\mathrm{Ca}^{++}$channels and related regulatory proteins, or acquired $(8,9)$. While inherited forms are relatively rare, with an estimated prevalence of $\sim 1: 2,000$ of apparently healthy newborns $(8,10)$, acquired LQTS is a quite frequent finding $(11,12)$, more commonly due to medications blocking the human ether-à-go-go related gene $\mathrm{K}^{+}$channel (hERG-K ${ }^{+}$) carrying the rapidly activating component of the delayed outward-rectifying current $\left(\mathrm{I}_{\mathrm{Kr}}\right)$, or electrolyte imbalances (hypokalaemia, hypocalcaemia, hypomagnesemia) $(1,9)$. Other well-defined causes of acquired LQTS include structural heart diseases, bradyarrhythmias, liver and endocrine diseases, nervous system injuries, starvation, hypothermia, and toxins $(9,13)$. Although wide, this list of "conventional" risk factors is not able to account for all cases of LQTS/TdP occurrence (and recurrence) in the clinical practice (4) and for this reason in the recent years, intensive investigations were undertaken to identify previously unrecognized risk factors. As a result, an increasing number of novel, "non-conventional" QT-prolonging risk factors for acquired LQTS have been recently recognized, including human immunodeficiency virus infection (14), male hypogonadism $(15,16)$, heart failure with preserved ejection fraction (17), QT-prolonging foods (18), inflammation and autoimmunity $(19,20)$.

Regarding the autoimmune LQTS, the most investigated form is associated to the presence of circulating antiRo/SSA-antibodies, responsible for one of the first identified arrhythmogenic autoantibody-induced channelopathies (autoimmune cardiac channelopathies) (19, 21, 22). In fact, accumulating evidence exists that anti-Ro/SSA-antibodies exert significant electrophysiological effects on the heart via an inhibitory cross-reaction with the extracellular pore region of the hERG-K ${ }^{+}$channel (23-27), leading to a higher propensity of developing LQTS (28-31) and VAs/TdP $(24,32,33)$ in antiRo/SSA-antibody positive adults and newborns subjects. In this review, we highlight the current knowledge on this autoimmune associated LQTS form providing complementary basic, clinical and population health perspectives.

\section{ANTI-Ro/SSA-ANTIBODIES}

Anti-Ro/SSA-antibodies, comprising the anti-Ro/SSA-52kD and anti-Ro/SSA-60kD sub-specificities, result from an autoimmune response against the two subunits of the intracellular ribonucleoprotein Ro (Ro52-kD and Ro60-kD) (34). They are polyclonal antibodies, usually of the IgG class, commonly found in patients with autoimmune diseases (AD) and beyond (34-36). In particular, anti-Ro/SSA-positivity is frequent in connective tissue diseases (CTD), primarily Sjögren's syndrome and systemic lupus erythermatosus (SLE) (34). In these disorders, anti-Ro/SSA-60kD sub-specificity has a more established direct pathogenic role than anti-Ro-52kD in the development of classical autoimmune manifestations (37, 38), also being associated with a higher prevalence of extraglandular features, especially vasculitis, and greater systemic activity $(39,40)$. Indeed, large studies have demonstrated that anti-Ro/SSAantibodies can be also detected in a significant proportion of subjects of the general population $(0.5-2.7 \%)(41-43)$, who are in most cases (60\%) asymptomatic for AD (43), particularly when anti-Ro/SSA-52kD positivity occurs alone (44).

Large evidence exists that the trans-placental passage of antiRo/SSA-antibodies from the mother to the fetus causes the autoimmune-congenital heart block ( $\mathrm{aCHB})(45)$, a paradigmatic form of passively acquired autoimmunity (46, 47). Although the pathogenesis of this disorder is complex and only in part elucidated, many clinical and experimental data have demonstrated that an inhibitory cross-reaction between antiRo/SSA-antibodies and the L- and T-type $\mathrm{Ca}^{++}$-channels in fetal conduction system cardiomyocytes plays a key mechanistic role (48-54).

In the clinical practice, several laboratory methods are available for anti-Ro/SSA-antibody detection, the more commonly used being immunoenzymatic tests (ELISA, FEIA) and line-blot immunoassay (LIA), all based on recombinant Ro antigens use as substrate $(34,36,55,56)$. However, increasing evidence indicates that immuno-Western blot (iWB), using the native Ro antigen, is the most sensitive technique to reveal anti-Ro/SSA-positivity in the general population (36) as well as arrhythmogenic autoantibodies in aCHB (57), more frequently being identified as the anti-Ro/SSA-52kD subtype (57).

\section{ANTI-Ro/SSA-ASSOCIATED LONG-QT SYNDROME}

\section{Clinical Data}

The first studies showing an association between anti-Ro/SSAantibodies and LQTS were performed in children in the early 2000s (Table 1). Cimaz et al. (28) reported that newbors/infants without aCHB from anti-Ro/SSA-positive mothers had longer QTc than anti-Ro/SSA-negative controls. Moreover, the same authors demonstrated that such alteration normalized spontaneously during the first year of life together with the 
TABLE 1 | Clinical studies showing an association between anti-Ro/SSA antibodies and QTc/TdP.

\begin{tabular}{|c|c|c|c|c|}
\hline References & Study population & $\begin{array}{c}\text { Anti- } \\
\text { Ro/SSA+ } \\
\text { (n) }\end{array}$ & $\begin{array}{c}\text { Anti- } \\
\text { Ro/SSA- } \\
\text { (n) }\end{array}$ & Main results \\
\hline
\end{tabular}

\section{Newborns/children}

Cimaz et al. (28)

Gordon et al. (58)

Cimaz et al. (59)

Jaeggi et al. (60)

AlTwajery et al. (61)

Friedman et al.

(62)

Duke et al. (63)

Wang et al. (64)

Mizuno et al. (65)

\section{Adults}

Lazzerini et al. (29)

Lazzerini et al. (32)

Bourrè-Tessier

et al. (30)

Lazzerini et al. (66)

CTD

AD

Pisoni et al. (67)

Sham et al. (68)

Nakamura et al.

(33)

Lazzerini et al. (24)

Perez-Garcia et al.

(69)

Tufan et al. (70)

CTD

SLE

TdP

TdP

SLE

CTD
Newborns of CTD

mothers

Children of CTD mothers

Children of

anti-Ro/SSA-positive

mothers

Newborns/children of

anti-Ro/SSA-positive

\section{mothers}

Children with SLE

Newborns/children of

anti-Ro/SSA-positive

mothers

Newborn of an anti-Ro/SSA-positive

mother

Child of an

anti-Ro/SSA-positive

mother

Child of an

anti-Ro/SSA-positive

mother
31

26

57

113

25

55

47

21

38

21

116

16

45

1

1

25

66

15
7

7

$-$

$-$

25

-

$-$
Mean QTc significantly longer in anti-Ro/SSA-positive subjects; QTC prolongation $>440 \mathrm{~ms}$ in $42 \%$ of cases (vs. 0\% in controls)

Mean QTc significantly longer in children of anti-Ro/SSA-positive mothers

Concomitant disappearance of QTc prolongation and acquired maternal antibodies at 1 year follow-up

Transient QTc prolongation > $440 \mathrm{~ms}$ in $15 \%$ of cases

Anti-Ro/SSA-positive patients showed higher prevalence of ECG abnormalities, particularly QTc prolongation > $450 \mathrm{~ms}$

QTC prolongation $>2$ SD above historical healthy controls in $11 \%$ of cases

QTC prolongation and ventricular tachycardia

QTc prolongation and TdP

QTc prolongation and TdP

Mean QTc significantly longer and prevalence of QTC

prolongation $>440 \mathrm{~ms}$ significantly higher in anti-Ro/SSA-positive subjects (58 vs. 0\%)

Mean QTc significantly longer and prevalence of QTC prolongation > $440 \mathrm{~ms}$ significantly higher in anti-Ro/SSA-positive subjects (46 vs. 5\%); QTc prolongation significantly associated with the presence of complex ventricular arrhythmias

5.1-12.6-times higher risk of QTc prolongation in anti-Ro/SSA positive vs. negative group. The risk of QTc prolongation directly correlated with anti-Ro/SSA concentration

Mean QTc significantly longer and prevalence of QTc prolongation $\geq$ $460 \mathrm{~ms}$ significantly higher in anti-Ro/SSA-positive subjects (48 vs. $17 \%)$; significant correlation between anti-Ro/SSA-52kD concentration and QTC duration

Anti-Ro/SSA positivity significantly more frequent among CTD patients with QTc prolongation $\geq 440 \mathrm{~ms}$ (all patients with QTc prolongation were anti-Ro/SSA positive, 20 vs. 0\%)

Mean QTc significantly longer in anti-Ro/SSA-positive subjects QTc prolongation and TdP in an anti-Ro/SSA-positive woman without AD

High prevalence of anti-Ro/SSA-52kD in unselected TdP patients (60\%)

Anti-Ro/SSA and anti-Ro/SSA-52kD levels significantly higher in patients with QTc prolongation, and linearly correlated with QTC duration

QTc max, Tp-e and Tp-e/QT ratio higher in anti-Ro/SSA-52kD-postive vs. negative CTD patients (and $\mathrm{HC}, n=22$ ); Tp-Te duration strongly correlated with anti-Ro/SSA-52kD titer 
TABLE 1 | Continued

\begin{tabular}{|c|c|c|c|c|}
\hline References & Study population & $\begin{array}{c}\text { Anti- } \\
\text { Ro/SSA+ } \\
\text { (n) }\end{array}$ & $\begin{array}{c}\text { Anti- } \\
\text { Ro/SSA- } \\
\text { (n) }\end{array}$ & Main results \\
\hline $\begin{array}{l}\text { Mostafavi et al. } \\
\text { (71) }\end{array}$ & SLE & 150 & - & $\begin{array}{l}\text { Anti-Ro/SSA positivity significantly associated with QTC } \\
\text { prolongation }>440 \mathrm{~ms}\end{array}$ \\
\hline Hu et al. (72) & SLE & 299 & - & $\begin{array}{l}\text { Anti-Ro/SSA positivity identified as one of the most important } \\
\text { independent variables associated with QTc prolongation }>450 \mathrm{~ms}\end{array}$ \\
\hline Lazzerini et al. (31) & US Veterans & 612 & 6,727 & $\begin{array}{l}\text { QTc prolongation (> } 470 \mathrm{~ms} \text { in males/> } 480 \mathrm{~ms} \text { in females) in } 10 \% \text { of } \\
\text { anti-Ro/SSA-positive vs. } 6.2 \% \text { of negative subjects (marked QTc } \\
\text { prolongation, > } 500 \mathrm{~ms}, 3.1 \mathrm{vs.} 1.0 \% \text { ). Anti-Ro/SSA positivity } \\
\text { independently associated with a } 2 \text {-times higher risk of marked QTc } \\
\text { prolongation (>500 ms; OR } 2.27,95 \% \mathrm{Cl} 1.34-3.87 \text { ) }\end{array}$ \\
\hline
\end{tabular}

CTD, connective tissue disease; AD, autoimmune disease; SLE, systemic lupus erythematosus; SSC, systemic sclerosis; HC, healthy controls; QTC, corrected QT interval; TdP, torsades de pointes; Tp-e, interval from the peak to the end of the T wave; Tp-e/QT ratio, interval from the peak to the end of the T wave/QT interval ratio.

disappearance of maternally-acquired anti-Ro/SSA-antibodies, thereby pointing to a functional and reversible interference on ventricular repolarization (59). Later, four independent groups provided data further supporting this association (Table 1). Gordon et al. (58) demonstrated that QTc was significantly prolonged in children from anti-Ro/SSA-positive mothers when compared to those from anti-Ro/SSA-negative mothers, with a more marked prolongation in siblings of a child with aCHB. Then, Jaeggi et al. (60) reported that in a Canadian cohort 116 anti-Ro/SSA-positive newborns/infants without aCHB, transient QTC prolongation was rather frequent, it being present in $15 \%$ of cases (60). Consistent data were more recently obtained by Friedman et al. (62) who analyzed the ECGs of 45 infants without $\mathrm{aCHB}$ born from anti-Ro/SSA-positive mothers and found that QTc prolongation > 2 standard deviations above historical healthy controls was present in $11 \%$ of subjects. Moreover, AlTwajery et al. (61) demonstrated that among 41 children affected with SLE, anti-Ro/SSA-positivity was associated with a higher prevalence of ECG abnormalities, particularly QTc prolongation $>450$ ms. Finally, three cases of marked QTc prolongation complicated with ventricular tachycardia/TdP in infants from anti-Ro/SSA-positive mothers with $\mathrm{aCHB}$ are reported (63-65).

In agreements with these findings, several studies demonstrated an increased prevalence of QTc prolongation and VAs in adults with circulating anti-Ro/SSA-antibodies (Table 1). Our group was the first to provide evidence that anti-Ro/SSA-positive adults with CTD frequently show QTc prolongation ( $>440 \mathrm{~ms}$ in $\sim 45-60 \%$ of cases) $(29,32)$, persisting throughout the $24 \mathrm{~h}$ and correlating with the risk of complex VAs (32). Later on, Bourré-Tessier et al. (30) conducted two consecutive studies on a larger cohort of SLE patients where anti-Ro/SSA-positivity was found to be associated with a 5-12times higher incidence of QTc prolongation, with a correlation with autoantibody levels. This latter finding was confirmed and refined by our group, by demonstrating that only the serum concentration of the anti-Ro/SSA-52kD subtype significantly and specifically associated with QTc duration (66).

After these seminal studies, many other authors provided clinical evidence supporting the existence of a relationship between anti-Ro/SSA-antibodies and QTc prolongation risk in adults (Table 1). Pisoni et al. (67) demonstrated that among 73 AD patients, the prevalence of QTc $>440 \mathrm{~ms}$ was significantly higher in anti-Ro/SSA-positive (20\%) vs. -negative subjects ( $0 \%)$. Consistent results were obtained by four subsequent studies, all conducted in SLE patients. Sham et al. (68) reported that mean QTc was longer in SLE subjects with, rather than without circulating anti-Ro/SSA-antibodies, while Mostafavi et al. (71) and Perez-Garcia et al. (69) found that anti-Ro/SSA-antibodies were more commonly detectable and at a higher concentration when SLE patients with QTc prolongation were compared to those with a normal QTc. Moreover, in a study using machine learning in 299 patients with SLE, Hu et al. (72) identified antiRo/SSA positivity as one of the most important independent variables associated with QTc prolongation $>450 \mathrm{~ms}$ in these subjects. Regarding the specific role of the anti-Ro/SSA-52kD subtype, Tufan et al. (70) reported increased QTc maximum and Tp-Te values in anti-Ro/SSA-52kD-positive CTD patients in comparison to negative patients and healthy controls. In addition, Perez-Garcia et al. (69) and Tufan et al. (70) found that anti-Ro/SSA-52kD levels were significantly associated with QTc and Tp-Te duration in SLE and CTD patients, respectively.

Further studies provided evidence that anti-Ro/SSAantibodies, regardless of the presence or absence of a clinically evident CTD/AD, are per se associated with LQTS/TdP (Table 1). This is a very important point, as it intriguingly suggests that these autoantibodies may represent a concealed risk factor possibly contributing to life-threatening VAs/SCD events in the general population (21). In fact, after the early case report by Nakamura et al. (33) of recurrent TdP episodes in an otherwise healthy anti-Ro/SSA-positive woman with circulating antiRo/SSA-antibodies, our group more in general demonstrated that circulating anti-Ro/SSA-antibodies are silently found in a significant proportion of unselected patients presenting with TdP. By analyzing a prospective cohort of $25 \mathrm{TdP}$ subjects consecutively collected from the general population, we found the presence of anti-Ro/SSA-52kD-antibodies in over $50 \%$ of patients, in most cases without a history of $\mathrm{AD}(24)$. In agreement with what was observed in children with $\mathrm{aCHB}$ (57) and patients with CTD (66), also in this case iWB was demonstrated to be the most sensitive laboratory technique in revealing arrhythmogenic autoantibodies. Strong support for these data is provided by 
TABLE 2 | Basic mechanisms of anti-Ro/SSA-associated LQTS: data from experimental studies.

\begin{tabular}{|c|c|c|c|c|}
\hline References & Effect on hERG-K+ & Effect on IKr & Effect on APD & Effect on QT interval \\
\hline $\begin{array}{l}\text { Nakamura } \\
\text { et al. (33) }\end{array}$ & $\begin{array}{l}\text { direct binding in HEK293-hERG cells } \\
\text { incubated with purified lgGs from an } \\
\text { anti-Ro/SSA-positive TdP patient }\end{array}$ & $\begin{array}{l}\text { chronic inhibition in HEK293-hERG cells } \\
\text { incubated with sera/purified lgGs from an } \\
\text { anti-Ro/SSA-positive TdP patient }\end{array}$ & - & - \\
\hline Yue et al. (23) & $\begin{array}{l}\text { 1. direct binding in HEK293-hERG cells } \\
\text { incubated with purified IgGs from } \\
\text { anti-Ro/SSA-positive CTD patients } \\
\text { with LQTS } \\
\text { 2. direct binding in HEK293-hERG cells } \\
\text { and guinea-pig ventricular tissue } \\
\text { incubated with anti-Ro/SSA-positive sera } \\
\text { from Ro52kD-immunized guinea-pigs } \\
\text { 3. cross-reactivity with a 31-amino acid } \\
\text { peptide corresponding to the pore-forming } \\
\text { region (segment S5-S6) incubated with } \\
\text { sera from anti-Ro/SSA-positive CTD } \\
\text { patients with LQTS }\end{array}$ & $\begin{array}{l}\text { 1. acute inhibition in HEK293-hERG cells } \\
\text { and/or guinea-pig ventricular myocytes } \\
\text { incubated with sera/purified } \\
\text { lgGs/affinity-purified anti-Ro/SSA-52kD } \\
\text { antibodies from anti-Ro/SSA-positive CTD } \\
\text { patients with LQTS } \\
\text { 2. acute inhibition in HEK293-hERG cells } \\
\text { incubated with anti-Ro/SSA-positive sera } \\
\text { from Ro52kD-immunized guinea-pigs }\end{array}$ & $\begin{array}{l}\text { prolongation in } \\
\text { guinea-pig ventricular } \\
\text { myocytes incubated } \\
\text { with purified lgGs from } \\
\text { anti-Ro/SSA-positive } \\
\text { CTD patients with } \\
\text { LQTS }\end{array}$ & $\begin{array}{l}\text { prolongation at the } \\
\text { surface ECG in } \\
\text { Ro52kD-immunized } \\
\text { guinea-pigs }\end{array}$ \\
\hline $\begin{array}{l}\text { Lazzerini et al. } \\
\text { (24) }\end{array}$ & $\begin{array}{l}\text { 1. direct binding in HEK293-hERG cells } \\
\text { incubated with purified IgGs from } \\
\text { anti-Ro/SSA-positive TdP patients } \\
\text { 2. cross-reactivity with a 31-amino acid } \\
\text { peptide corresponding to the pore-forming } \\
\text { region (segment S5-S6) incubated with } \\
\text { sera from anti-Ro/SSA-positive } \\
\text { TdP patients }\end{array}$ & $\begin{array}{l}\text { acute inhibition in HEK293-hERG cells } \\
\text { incubated with purified IgGs from } \\
\text { anti-Ro/SSA-positive TdP patients }\end{array}$ & - & - \\
\hline $\begin{array}{l}\text { Fabris et al. } \\
(26)\end{array}$ & - & $\begin{array}{l}\text { acute inhibition in HEK293-hERG cells and } \\
\text { guinea-pig ventricular myocytes incubated } \\
\text { with sera from guinea-pigs immunized } \\
\text { with a 31-amino acid peptide } \\
\text { corresponding to the hERG pore-forming } \\
\text { region (E-pore peptide) and cross-reacting } \\
\text { with sera from anti-Ro/SSA-positive CTD } \\
\text { patients with LQTS }\end{array}$ & $\begin{array}{l}\text { prolongation in } \\
\text { guinea-pig ventricular } \\
\text { myocytes incubated } \\
\text { with sera from E-pore } \\
\text { peptide-immunized } \\
\text { guinea-pigs }\end{array}$ & $\begin{array}{l}\text { prolongation at the } \\
\text { surface ECG in E-pore } \\
\text { peptide-immunized } \\
\text { guinea-pigs }\end{array}$ \\
\hline $\begin{array}{l}\text { Szendrey } \\
\text { et al. ( } 27)\end{array}$ & $\begin{array}{l}\text { 1. direct binding to the extracellular } \\
\text { S5-pore linker in HEK293-hERG cells } \\
\text { incubated with commercial } \\
\text { anti-Ro/SSA-52kD antibodies } \\
\text { 2. decreased expression with enhanced } \\
\text { endocytic degradation in HEK293-hERG } \\
\text { cells incubated with commercial } \\
\text { anti-Ro/SSA-52kD antibodies }\end{array}$ & $\begin{array}{l}\text { chronic inhibition in HEK293-hERG cells } \\
\text { and neonatal rat ventricular myocytes } \\
\text { incubated with sera from } \\
\text { anti-Ro/SSA-52kD-positive CTD patients } \\
\text { or commercial anti-Ro/SSA-52kD } \\
\text { antibodies }\end{array}$ & $\begin{array}{l}\text { prolongation in } \\
\text { neonatal rat ventricular } \\
\text { myocytes chronically } \\
\text { incubated with } \\
\text { commercial } \\
\text { anti-Ro/SSA-52kD } \\
\text { antibodies }\end{array}$ & - \\
\hline
\end{tabular}

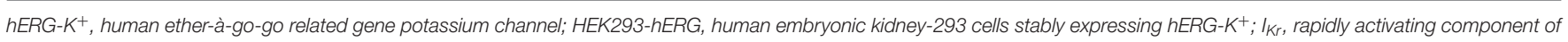

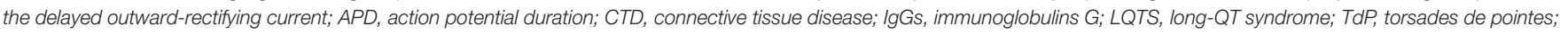
ECG, electrocardiogram.

a very recent population study conducted in a large cohort of 7339 US Veterans, including 612 anti-Ro/SSA-positive (31). In these subjects, circulating anti-Ro/SSA-antibodies were independently associated with a $\sim 2$-times higher risk of marked QTc prolongation $(>500 \mathrm{~ms})$, regardless the presence or not of history of CTD. Moreover, stepwise multivariate logistic regression analysis demonstrated that anti-Ro/SSA positivity was one of the most important contributors to marked QTc prolongation, with a significant synergy with most of the concomitant traditional QT-prolonging risk factors, including antimalarials (31). In fact, accumulating evidence demonstrates that this class of drugs, commonly used for the treatment of CTD patients, can inhibit the hERG- $\mathrm{K}^{+}$-channel (73-75) and promote LQTS development (76). Nevertheless, by stratifying Veterans according the antimalarials use, it was demonstrated that even in the absence of these drugs subjects who were antiRo/SSA-positive showed a prevalence of QTc > 500 two-fold higher than in those who were anti-Ro/SSA-negative (31).

Besides the aforementioned studies, it should be noted how other authors reported that adult or pediatric anti-Ro/SSApositive patients showed increased QTc duration and/or QTC prolongation prevalence with respect to negative controls. However, such differences approached but did not reach the statistical significance, most likely because of the undersized samples used. This is the case of four additional studies reporting slightly longer mean QTc (Gordon et al., $p=0.06$; Motta et al., $p=0.06)(77,78)$ or higher proportion of QTc prolongation (Nomura et al., $p=0.08$; BourréTessier et al., wide 95\%CI) $(79,80)$ in the presence of circulating anti-Ro/SSA-antibodies. 
While this large body of data provides robust evidence for a clinically significant association between anti-Ro/SSAantibodies and LQTS risk, some studies involving children $(81,82)$ or adults $(83-87)$ reported apparently conflicting results. Several factors may account for these discrepancies, also possibly contributing to the significant variability in antiRo/SSA-associated QTc prolongation frequencies even reported by positive association studies $(\sim 10-60 \%)(25,66)$. Firstly, given that the QT-prolonging effects seems to be specifically due to the anti-Ro/SSA-52kD subtype, and in a concentration-dependent manner $(23,24,27,66,69,70)$, it is likely that patients in these cohorts did not present circulating levels of this autoantibody sufficient to produce measurable electrocardiographic changes. Indeed, among different CTDs, a wide variability exists in terms of anti-Ro/SSA-52kD concentrations (for example, in systemic sclerosis patients the antibody level is typically low) $(85,88,89)$, and in most of the negative association studies specific subtype assessment was not executed. In addition, most of these studies were retrospective and utilized different cutoffs to define QTc prolongation, these factors also potentially contributing to inconsistencies. This is the case, for example, of the study by Teixeira et al. (83) in which the QTc was considered as prolonged when $>500 \mathrm{~ms}$. As a result, only 10 out of 317 SLE patients showed QTc prolongation, a sample size that is underpowered for any statistical comparison between anti-Ro/SSA-positive $(4 / 111,3.6 \%)$ and -negative subjects (83). Data from the recent population study on US Veterans provide new important details, which provide support to the above considerations (31). In fact, in this large cohort, where only the qualitative data of anti-Ro/SSA-positivity was considered (no information on antibody subtypes and related concentrations available) the overall prevalence of QTc prolongation $>470 \mathrm{~ms}$ (males) $/ 480 \mathrm{~ms}$ (females) in anti-Ro/SSApositive subjects was $10 \%$ (vs. $6.2 \%$ in anti-Ro/SSA-negative, $p<0.001$ ) (31), a percentage underestimated since several individuals without/with low levels of anti-Ro/SSA-52kD subtype were certainly present among those labeled as anti-Ro/SSApositive. Notably, $3.1 \%$ of the subjects with circulating antiRo/SSA-antibodies (vs. 1.1\% in anti-Ro/SSA-negative) showed QTc prolongation $>500 \mathrm{~ms}$, proportions in part similar to those found by Teixeira et al., (83) but in this case very different from a statistical point of view $(p<0.001)$ due to the adequate power of the sample size (31).

Finally, as discussed in more details in the following section "Experimental Data," anti-Ro/SSA-antibodies can concomitantly inhibit multiple cardiac ion channels, resulting in conflicting effects on APD, thereby on QT interval duration on the surface ECG $(21,90)$. Such a multifaceted impact on cardiomyocyte electrophysiology, along with the inherent (genetic and acquired) variability in cardiac ion channels reserves among different individuals (91, 92), may also significantly contribute to the reported discrepancies among clinical studies $(21,90)$.

\section{Experimental Data}

Accumulating data from experimental studies based on invitro, ex-vivo, and in-vivo models (Table 2) $(23,24,26,27,33)$ demonstrated that the QT-prolonging effect of anti-Ro/SSAantibodies, specifically the anti-Ro/SSA-52kD subtype, is due to a specific cross-reaction with the cardiac hERG-K ${ }^{+}$channel leading to an inhibition of the related current, $\mathrm{I}_{\mathrm{Kr}}$ (21). The direct electrophysiological nature of such an effect can well explain why circulating anti-Ro/SSA-antibodies are per se associated with an increased risk of QTc prolongation/TdP in the clinical setting, regardless of the presence or not of an overt $\mathrm{AD}(24$, 31).

Specifically, our group demonstrated that incubation of human embryonic kidney-293 cells stably expressing the hERG-K ${ }^{+}$-channel (HEK293-hERG) or guinea-pig ventricular myocytes with serum, purified IgGs, or affinity-purified anti-Ro/SSA-52kD obtained from CTD patients with LQTS was associated with an acute (minutes), concentrationdependent and reversible $\mathrm{I}_{\mathrm{Kr}}$ inhibition (23). Moreover, the development of high levels of circulating anti-Ro/SSA$52 \mathrm{kD}$ antibodies in guinea-pigs immunized with the Ro52 antigen was associated with an evident prolongation of the APD measured in ventricular myocytes, as well as of the QTc measured at the surface ECG (23). Furthermore, by combining $\mathrm{WB}$ and ELISA experiments, we also provided evidence that anti-Ro/SSA-antibodies can directly crossreact with the $\mathrm{hERG}-\mathrm{K}^{+}$-channel, specifically with the S5-S6 segments of the extracellular loop of the pore region where a significant sequence homology with the Ro52 antigen was demonstrated (23). Consistently, the immunization of guinea-pigs with a 31-amino acid peptide corresponding to this region of the $\mathrm{hERG}-\mathrm{K}^{+}$-channel resulted in high levels antibodies able to block $\mathrm{I}_{\mathrm{Kr}}$, prolong $\mathrm{APD}$ and QTc, in the absence of any structural change at the pathology examination of the myocardium (26). In addition, a recent Canadian study provided further mechanistic insights into anti-Ro/SSA-associated QTc prolongation, explaining its longlasting persistence as observed in the clinical setting (27). In fact, these authors demonstrated that prolonged incubation of HEK293-hERG cells with anti-Ro/SSA-52kD-positive sera from patients with rheumatic diseases significantly decreased $\mathrm{I}_{\mathrm{Kr}}$ compared to cells treated with autoantibody-negative patients' sera (27). Moreover, they showed that anti-Ro/SSA$52 \mathrm{kD}$ antibodies chronically facilitated hERG endocytic degradation by targeting the extracellular S5-pore linker region of the channel, and that these changes were associated with persistent $\mathrm{I}_{\mathrm{Kr}}$ reduction and APD prolongation in neonatal rat ventricular myocytes (27)

The same mechanisms are implicated in anti-Ro/SSA-positive subjects who develop TdP, despite the absence of a manifest $\mathrm{AD}$ (Table 2). The first evidence was provided by Nakamura et al. (33) who demonstrated that serum and purified IgGs from an otherwise healthy anti-Ro/SSA-positive woman presenting with marked QTc prolongation and recurring TdP, crossreacted with the hERG- $\mathrm{K}^{+}$-channel and chronically blocked $\mathrm{I}_{\mathrm{Kr}}$ in HEK293-hERG cells. Our group confirmed and refined these findings in a prospective cohort of 25 consecutive TdP patients, including $15(60 \%)$ with circulating anti-Ro/SSA$52 \mathrm{kD}$ antibodies, in most cases $(13 / 15,87 \%)$ without a history 

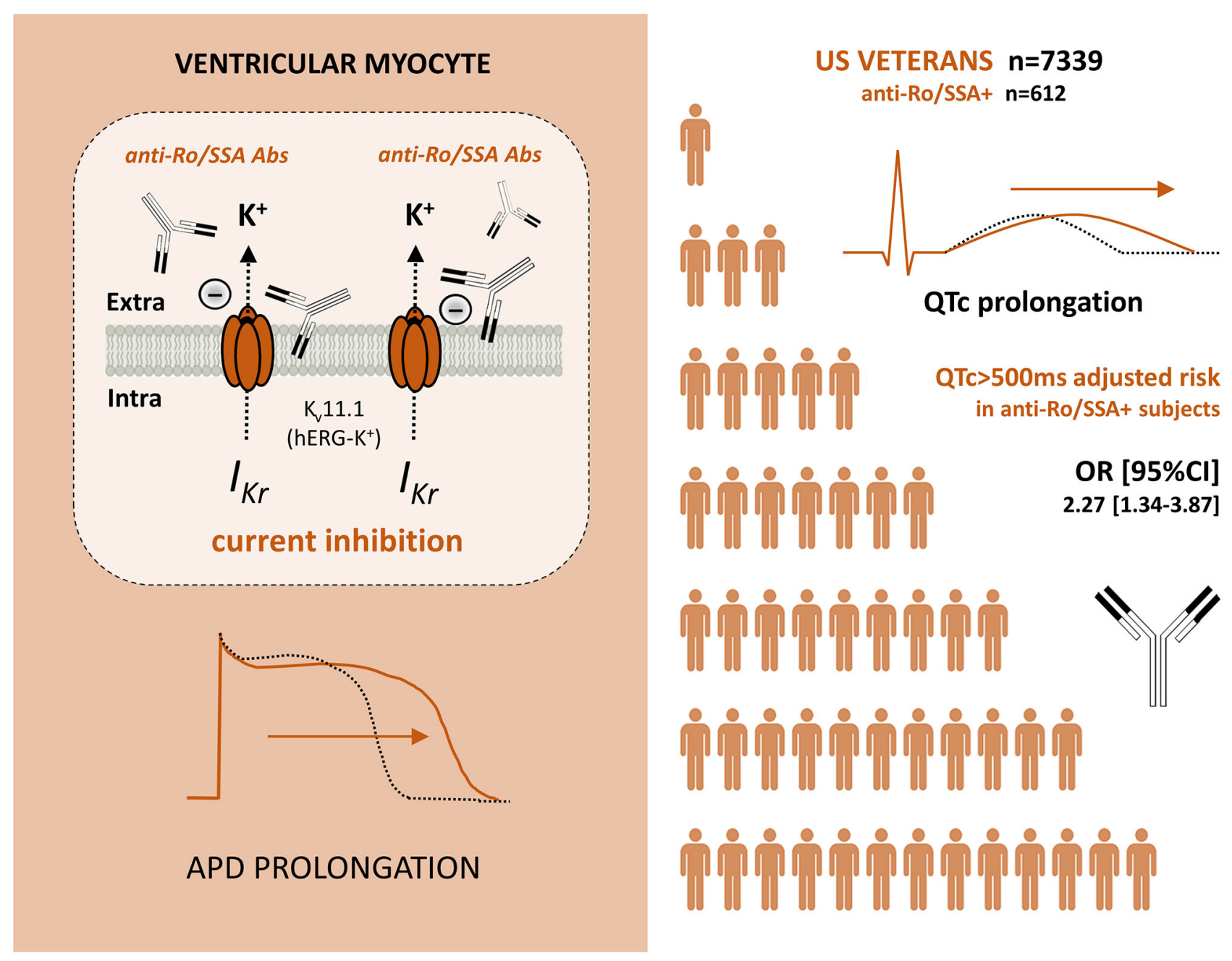

OR $[95 \% \mathrm{Cl}]$ 2.27 [1.34-3.87]

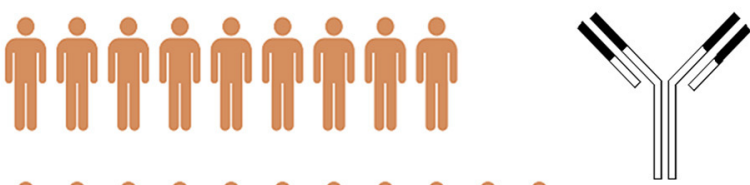

FIGURE 1 | Anti-Ro/SSA antibodies, which can inhibit the $\mathrm{I}_{\mathrm{kr}}$ current by directly recognizing $\mathrm{hERG}$ potassium channel (brownish), are independently associated with an increased risk of marked QTc prolongation in a large cohort of Veterans (white). Abs, Antibodies; $I_{\mathrm{Kr}}$, rapidly activating component of the delayed outward-rectifying $\mathrm{K}^{+}$current; hERG-K+ $\mathrm{K}^{+}$, human ether-à-go-go related gene potassium channel; APD, Action potential duration; QTc, heart rate-corrected QT-interval; OR, odds ratio; $\mathrm{Cl}$, confidence interval.

of $\mathrm{AD}$ (24). Again, sera and IgGs from anti-Ro/SSA-52kDpositive subjects significantly reduced $\mathrm{I}_{\mathrm{Kr}}$ in HEK293-hERG cells, but also in guinea-pig ventricular myocytes, and recognized the hERG- $\mathrm{K}^{+}$-channel by specifically interacting with the S5S6 segment of the extracellular loop of the pore-forming region (24).

Altogether, these data robustly support the hypothesis that a direct hERG- $\mathrm{K}^{+}$-channel blockade is the molecular mechanism underlying QTc prolongation and TdP observed in anti-Ro/SSApositive subjects. However, it should be noted that anti-Ro/SSAantibodies can also cross-react with and block cardiac $\mathrm{Ca}^{++}$ channels $(48,50-52,54)$, responsible for opposite effects on APD. This view is supported by a mathematical modeling study which demonstrated how a simultaneous anti-Ro/SSA-associated inhibition of $\mathrm{I}_{\mathrm{CaL}}$ during the plateau phase partly counterbalances the APD prolonging effect due to $\mathrm{I}_{\mathrm{Kr}}$ decrease (26). Based on this evidence, it is likely that the inherent ion channel reserve which characterize each single subject (92) may significantly influence the overall impact of anti-Ro/SSA-antibodies on the duration of the QTc on the surface ECG, thereby contributing to explain the inconsistencies among clinical studies on the association of anti-Ro/SSA-antibodies and QTc prolongation (25). However, given that $\mathrm{I}_{\mathrm{Kr}}$ physiologically activates after the T wave peak on the ECG $(6,93)$, a specific evaluation of the $\mathrm{Tp}$-Te might represent a more accurate method to assess in the clinical setting, the discrete impact of anti-Ro/SSA-antibodies on this current. This also in consideration of the particularly important prognostic role that $\mathrm{Tp}$ - Te prolongation seems to have in predicting $\mathrm{TdP}$ risk $(4,5)$. In agreement with such premises, Tufan et al. (70) demonstrated that in anti-Ro/SSA52kD-positive CTD patients Tp-Te was significantly prolonged when compared to anti-Ro/SSA-52kD-negative patients and healthy controls, even in those in whom the whole duration of the QTc was normal. 


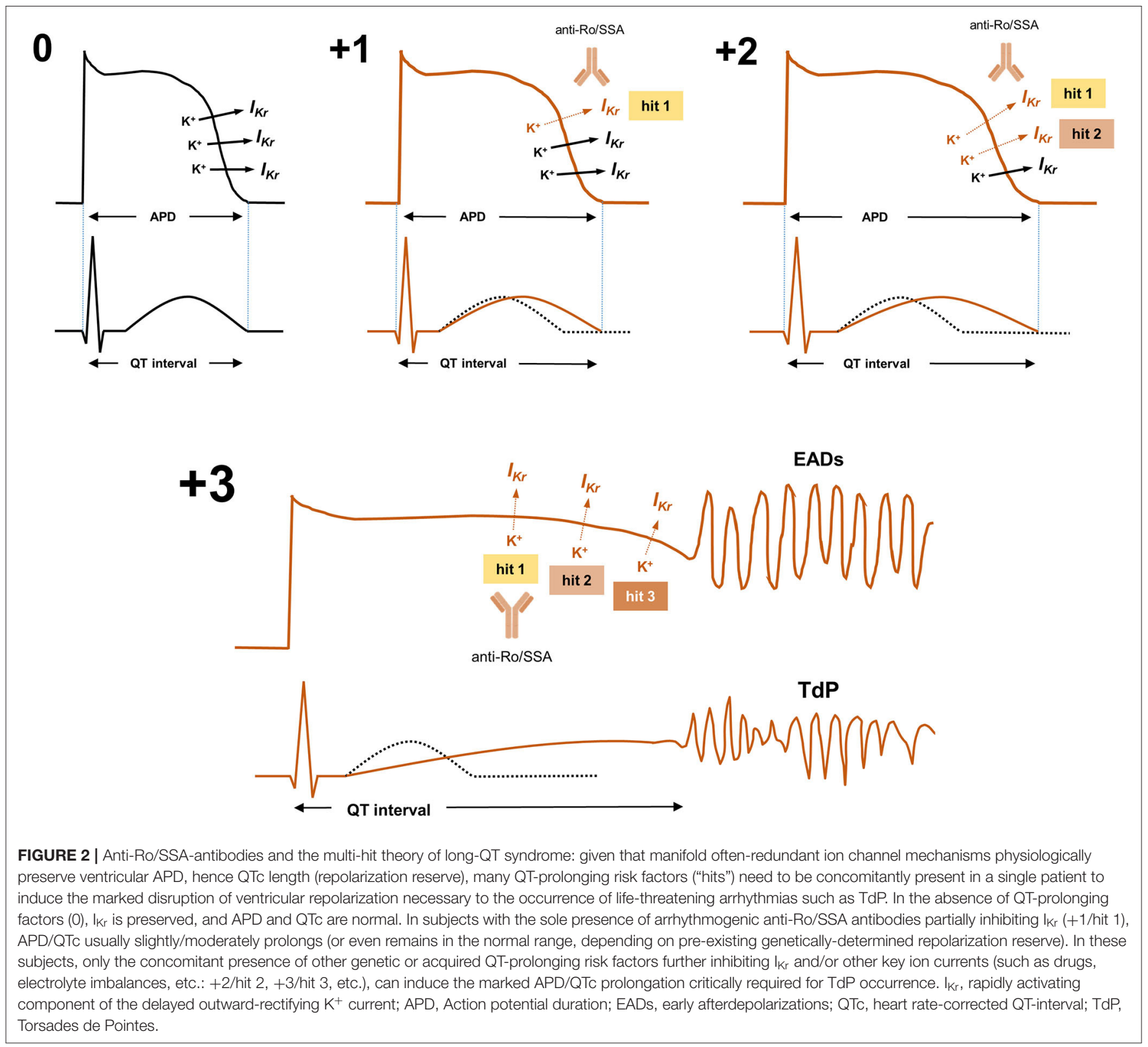

\section{CONCLUSIONS}

Mounting evidence from clinical and experimental studies indicates that anti-Ro/SSA-antibodies can markedly affect the ventricular repolarization via a direct inhibitory cross-reaction with the extracellular pore region of the cardiac hERG- $\mathrm{K}^{+}$channel, resulting in an increased predisposition to LQTS/TdP in anti-Ro/SSA-positive patients. Notably, recent data demonstrate that such a risk is increased independent of a history of overt $\mathrm{AD}$, intriguingly suggesting that these autoantibodies may also silently contribute to a number of cases of VAs and cardiac arrest in the general population (Figure 1).

In fact, although anti-Ro/SSA-antibodies alone cannot usually prolong QTc in a so critical manner to induce TdP development (similarly to all the other better recognized determinants of
LQTS) (91, 94), nevertheless they can reduce the ventricular repolarisation reserve (92), thereby enhancing the arrhythmic risk when other conventional QT-prolonging factors (drugs, electrolyte imbalances, genetic mutations, etc.) are concomitantly present (multi-hit theory) (Figure 2) (24, 91, 95-99).

Based on these considerations and in some way referring to the existing guidelines on the approach to aCHB (100), it is recommended that anti-Ro/SSA-positive subjects receive serial ECGs and specific counseling about medications and management of other risk factors that may critically enhance the risk for QT-associated malignant arrhythmias. On the other hand, patients with "idiopathic" rhythm disturbances should be considered for specific anti-Ro/SSA testing (iWB technique is recommended for detecting arrhythmogenic antiRo/SSA subtypes), regardless the presence or not of a manifest 
$\mathrm{AD}$, given that the demonstration of circulating antibodies may lead to innovative therapeutic opportunities. Indeed, in agreement with current recommendations for incomplete forms of $\mathrm{aCHB}$ (100) (and with several case reports showing the reversing effects of immunosuppressive therapy in antiRo/SSA-associated atrioventricular blocks in adults) (101104), preliminary data from anti-Ro/SSA-positive CTD patients suggest that a short course immunomodulating treatment with corticosteroids is associated with a significant QTc shortening $(104,105)$. Larger studies are warranted to confirm these intriguing findings. Moreover, given that anti-Ro/SSA-antibodies prolong APD/QTc by directly reacting with a specific amino acid sequence of the hERG-K ${ }^{+}$channel, a peptide-based therapy serving as a decoy to prevent autoantibody-channel binding may be another innovative approach, as preliminarily supported by ex-vivo data on sera from anti-Ro/SSA-positive TdP subjects (24).

\section{AUTHOR CONTRIBUTIONS}

PL: conception and design of the work and drafting the work. PL, FL-P, MB, and PC: final approval of the version

\section{REFERENCES}

1. Drew BJ, Ackerman MJ, Funk M, Gibler WB, Kligfield P, Menon V, et al. Prevention of torsade de pointes in hospital settings: a scientific statement from the American Heart Association and the American College of Cardiology Foundation. Circulation. (2010) 121:1047-60. doi: 10.1161/CIRCULATIONAHA.109.192704

2. Moss AJ. Long QT syndrome. JAMA. (2003) 289:2041-4. doi: 10.1001/jama.289.16.2041

3. El-Sherif N, Turitto G. Torsade de pointes. Curr Opin Cardiol. (2003) 18:6-13. doi: 10.1097/00001573-200301000-00002

4. Drew BJ, Ackerman MJ, Funk M, Gibler WB, Kligfield P, Menon V, et al. Prevention of torsade de pointes in hospital settings: a scientific statement from the American Heart Association and the American College of Cardiology Foundation. J Am Coll Cardiol. (2010) 55:934-47. doi: 10.1016/j.jacc.2010.01.001

5. Panikkath R, Reinier K, Uy-Evanado A, Teodorescu C, Hattenhauer J, Mariani R, et al. Prolonged Tpeak-to-tend interval on the resting ECG is associated with increased risk of sudden cardiac death. Circ Arrhythm Electrophysiol. (2011) 4:441-7. doi: 10.1161/CIRCEP.110. 960658

6. Grant AO. Cardiac ion channels. Circ Arrhythm Electrophysiol. (2009) 2:18594. doi: 10.1080/19336950.2015.1076597

7. Obeyesekere MN, Antzelevitch C, Krahn AD. Management of ventricular arrhythmias in suspected channelopathies. Circ Arrhythm Electrophysiol. (2015) 8:221-31. doi: 10.1161/CIRCEP.114.002321

8. El-Sherif N, Turitto G, Boutjdir M. Congenital long QT syndrome and torsade de pointes. Ann Noninvasive Electrocardiol. (2017) 22:e12481. doi: $10.1111 /$ anec. 12481

9. El-Sherif N, Turitto G, Boutjdir M. Acquired long QT syndrome and torsade de pointes. Pacing Clin Electrophysiol. (2018) 41:414-21. doi: 10.1111 /pace.13296

10. Schwartz PJ, Stramba-Badiale M, Crotti L, Pedrazzini M, Besana A, Bosi G, et al. Prevalence of the congenital long-QT syndrome. Circulation. (2009) 120:1761-7. doi: 10.1161/CIRCULATIONAHA.109.863209

11. Tisdale JE, Wroblewski HA, Overholser BR, Kingery JR, Trujillo TN, Kovacs RJ. Prevalence of QT interval prolongation in patients admitted to cardiac care units and frequency of subsequent administration of QT to be published. FL-P, MB, and PC: revising the draft of the work critically for important intellectual content and agreement to be accountable for all aspects of the work in ensuring that questions related to the accuracy or integrity of any part of the work are appropriately investigated and resolved. All authors contributed to the article and approved the submitted version.

\section{FUNDING}

This work was funded by: 1) Ministero dell'Istruzione, dell'Università e della Ricerca (MIUR), Progetti di Rilevante Interesse Nazionale (PRIN), and Bando 2017, protocollo 2017XZMBYX; and 2) Biomedical Laboratory Research and Development Service of Veterans Affairs Office of Research and Development (Merit Review Grant I01 BX002137 to Dr. Boutjdir).

\section{ACKNOWLEDGMENTS}

We thank Dr. Andrea Francioni for his contribution to the Figure 2.

interval-prolonging drugs: a prospective, observational study in a large urban academic medical center in the US. Drug Saf. (2012) 35:459-70. doi: 10.2165/11598160-000000000-00000

12. Tisdale JE. Prevalence and significance of acquired QT interval prolongation in hospitalized patients. Heart Rhythm. (2017) 14:979-80. doi: 10.1016/j.hrthm.2017.03.036

13. Viskin S. Long QT syndromes and torsade de pointes. Lancet. (1999) 354:1625-33. doi: 10.1016/S0140-6736(99)02107-8

14. Brouillette J, Cyr S, Fiset C. Mechanisms of arrhythmia and sudden cardiac death in patients with HIV infection. Can J Cardiol. (2019) 35:310-9. doi: 10.1016/j.cjca.2018.12.015

15. Salem JE, Waintraub X, Courtillot C, Shaffer CM, Gandjbakhch E, Maupain C, et al. Hypogonadism as a reversible cause of torsades de pointes in men. Circulation. (2018) 138:110-3. doi: 10.1161/CIRCULATIONAHA.118.034282

16. Lazzerini PE, Bertolozzi I, Acampa M, Cantara S, Castagna MG, Pieragnoli L, et al. Androgen deprivation therapy for prostatic cancer in patients with torsades de pointes. Front Pharmacol. (2020) 11:684. doi: 10.3389/fphar.2020.00684

17. Cho JH, Zhang R, Kilfoil PJ, Gallet R, de Couto G, Bresee C, et al. Delayed repolarization underlies ventricular arrhythmias in rats with heart failure and preserved ejection fraction. Circulation. (2017) 136:2037-50. doi: 10.1161/CIRCULATIONAHA.117.028202

18. Woosley RL. Arrhythmogenic foods - a growing medical problem. Trends Cardiovasc Med. (2019) 30:310-2. doi: 10.1016/j.tcm.2019.08.007

19. Lazzerini PE, Laghi-Pasini F, Boutjdir M, Capecchi PL. Cardioimmunology of arrhythmias: the role of autoimmune and inflammatory cardiac channelopathies. Nat Rev Immunol. (2019) 19:63-4. doi: 10.1038/s41577-018-0098-z

20. Lazzerini PE, Hamilton RM, Boutjdir M. Editorial: cardioimmunology: inflammation and immunity in cardiovascular disease. Front Cardiovasc Med. (2019) 6:181. doi: $10.3389 /$ fcvm.2019. 00181

21. Lazzerini PE, Capecchi PL, Laghi-Pasini F, Boutjdir M. Autoimmune channelopathies as a novel mechanism in cardiac arrhythmias. Nat Rev Cardiol. (2017) 14:521-35. doi: 10.1038/nrcardio.2017.61

22. Lazzerini PE, Capecchi PL, Acampa M, Selvi E, Guideri F, Bisogno $\mathrm{S}$, et al. Arrhythmogenic effects of anti-Ro/SSA antibodies on the 
adult heart: more than expected? Autoimmun Rev. (2009) 9:40-4. doi: 10.1016/j.autrev.2009.03.002

23. Yue Y, Castrichini M, Srivastava U, Fabris F, Shah K, Li Z, et al. Pathogenesis of the novel autoimmune-associated long-QT syndrome. Circulation. (2015) 132:230-40. doi: 10.1161/CIRCULATIONAHA.115.009800

24. Lazzerini PE, Yue Y, Srivastava U, Fabris F, Capecchi PL, Bertolozzi I, et al. Arrhythmogenicity of Anti-Ro/SSA antibodies in patients with torsades de pointes. Circ Arrhythm Electrophysiol. (2016) 9:e003419. doi: 10.1161/CIRCEP.115.003419

25. Boutjdir M, Lazzerini PE, Capecchi PL, Laghi-Pasini F, El-Sherif N. Potassium channel block and novel autoimmune-associated long QT syndrome. Card Electrophysiol Clin. (2016) 8:373-84. doi: 10.1016/j.ccep.2016.02.002

26. Fabris F, Yue $\mathrm{Y}, \mathrm{Qu} \mathrm{Y}$, Chahine M, Sobie E, Lee $\mathrm{P}$, et al. Induction of autoimmune response to the extracellular loop of the HERG channel pore induces QTc prolongation in guinea-pigs. J Physiol. (2016) 594:6175-87. doi: 10.1113/JP272151

27. Szendrey J, Lamothe SM, Vanner S, Guo J, Yang T, Li W, et al. Anti-Ro52 antibody acts on the S5-pore linker of hERG to chronically reduce channel expression. Cardiovasc Res. (2019) 115:1500-11. doi: 10.1093/cvr/cvy310

28. Cimaz R, Stramba-Badiale M, Brucato A, Catelli L, Panzeri P, Meroni PL. QT interval prolongation in asymptomatic anti-SSA/Ro-positive infants without congenital heart block. Arthritis Rheum. (2000) 43:1049-53. doi: 10.1002/1529-0131(200005)43:5<1049::AID-ANR13>3.0.CO;2-X

29. Lazzerini PE, Acampa M, Guideri F, Capecchi PL, Campanella V, Morozzi G, et al. Prolongation of the corrected QT interval in adult patients with anti-Ro/SSA-positive connective tissue diseases. Arthritis Rheum. (2004) 50:1248-52. doi: 10.1002/art.20130

30. Bourré-Tessier J, Clarke AE, Huynh T, Bernatsky S, Joseph L, Belisle $\mathrm{P}$, et al. Prolonged corrected QT interval in anti-Ro/SSA-positive adults with systemic lupus erythematosus. Arthritis Care Res. (2011) 63:1031-7. doi: 10.1002/acr.20470

31. Lazzerini PE, Cevenini G, Qu YS, Fabris F, El-Sherif N, Acampa M, et al. Risk of QTc interval prolongation associated with circulating Anti-Ro/SSA antibodies among US veterans: an observational cohort study. J Am Heart Assoc. (2021) 2021:e018735. doi: 10.1161/JAHA.120.018735

32. Lazzerini PE, Capecchi PL, Guideri F, Bellisai F, Selvi E, Acampa M, et al. Comparison of frequency of complex ventricular arrhythmias in patients with positive versus negative anti-Ro/SSA and connective tissue disease. Am J Cardiol. (2007) 100:1029-34. doi: 10.1016/j.amjcard.2007.04.048

33. Nakamura K, Katayama Y, Kusano KF, Haraoka K, Tani Y, Nagase S, et al. Anti-KCNH2 antibody-induced long QT syndrome: novel acquired form of long QT syndrome. J Am Coll Cardiol. (2007) 50:1808-9. doi: 10.1016/j.jacc.2007.07.037

34. Franceschini F, Cavazzana I. Anti-Ro/SSA and La/SSB antibodies. Autoimmunity. (2005) 38:55-63. doi: 10.1080/08916930400022954

35. Burbelo $\mathrm{PD}$, Ching $\mathrm{KH}$, Han $\mathrm{BL}$, Bush ER, Reeves WH, Iadarola MJ. Extraordinary antigenicity of the human Ro52 autoantigen. Am J Transl Res. (2010) 2:145-55.

36. Metsküla K, Salur L, Mandel M, Uibo R. Demonstration of high prevalence of SS-A antibodies in a general population: association with HLA-DR and enterovirus antibodies. Immunol Lett. (2006) 106:14-8. doi: 10.1016/j.imlet.2006.03.005

37. Scofield RH, Kaufman KM, Baber U, James JA, Harley JB, Kurien BT. Immunization of mice with human $60-\mathrm{kd}$ Ro peptides results in epitope spreading if the peptides are highly homologous between human and mouse. Arthritis Rheum. (1999) 42:1017-24. doi: 10.1002/1529-0131(199905)42:5 < 1017::AID-ANR22>3.0.CO;2-7

38. Kurien BT, Dsouza A, Igoe A, Lee YJ, Maier-Moore JS, Gordon T, et al. Immunization with $60 \mathrm{kD}$ Ro peptide produces different stages of preclinical autoimmunity in a Sjögren's syndrome model among multiple strains of inbred mice. Clin Exp Immunol. (2013) 173:67-75. doi: 10.1111/cei. 12094

39. Harley JB, Alexander EL, Bias WB, Fox OF, Provost TT, Reichlin M, et al. Anti-Ro (SS-A) and anti-La (SS-B) in patients with Sjögren's syndrome. Arthritis Rheum. (1986) 29:196-206. doi: 10.1002/art.1780290207

40. Brito-Zerón P, Acar-Denizli N, Ng WF, Zeher M, Rasmussen A, Mandl $\mathrm{T}$, et al. How immunological profile drives clinical phenotype of primary
Sjögren's syndrome at diagnosis: analysis of 10,500 patients (Sjögren Big Data Project). Clin Exp Rheumatol. (2018) 36(Suppl 112):102-12.

41. Satoh M, Chan EK, Ho LA, Rose KM, Parks CG, Cohn RD, et al. Prevalence and sociodemographic correlates of antinuclear antibodies in the United States. Arthritis Rheum. (2012) 64:2319-27. doi: 10.1002/art.34380

42. Guo YP, Wang CG, Liu X, Huang YQ, Guo DL, Jing XZ, et al. The prevalence of antinuclear antibodies in the general population of china: a cross-sectional study. Curr Ther Res Clin Exp. (2014) 76:116-9. doi: 10.1016/j.curtheres.2014.06.004

43. Hayashi N, Koshiba M, Nishimura K, Sugiyama D, Nakamura T, Morinobu $\mathrm{S}$, et al. Prevalence of disease-specific antinuclear antibodies in general population: estimates from annual physical examinations of residents of a small town over a 5-year period. Mod Rheumatol. (2008) 18:153-60. doi: 10.3109/s10165-008-0028-1

44. Hervier B, Rimbert M, Colonna F, Hamidou MA, Audrain M. Clinical significance of anti-Ro/SSA-52 $\mathrm{kDa}$ antibodies: a retrospective monocentric study. Rheumatology. (2009) 48:964-7. doi: 10.1093/rheumatology/kep145

45. Brucato A, Cimaz R, Caporali R, Ramoni V, Buyon J. Pregnancy outcomes in patients with autoimmune diseases and anti-Ro/SSA antibodies. Clin Rev Allergy Immunol. (2011). 40:27-41. doi: 10.1007/s12016-009-8190-6

46. Brito-Zerón P, Izmirly PM, Ramos-Casals M, Buyon JP, Khamashta MA. The clinical spectrum of autoimmune congenital heart block. Nat Rev Rheumatol. (2015) 11:301-12. doi: 10.1038/nrrheum.2015.29

47. Lazzerini PE, Capecchi PL, Laghi-Pasini F. Anti-Ro/SSA antibodies and cardiac arrhythmias in the adult: facts and hypotheses. Scand J Immunol. (2010) 72:213-22. doi: 10.1111/j.1365-3083.2010.02428.x

48. Karnabi E, Boutjdir M. Role of calcium channels in congenital heart block. Scand J Immunol. (2010) 72:226-34. doi: 10.1111/j.1365-3083.2010.02439.x

49. Qu YS, Lazzerini PE, Capecchi PL, Laghi-Pasini F, El Sherif N, Boutjdir M. Autoimmune calcium channelopathies and cardiac electrical abnormalities. Front Cardiovasc Med. (2019) 6:54. doi: 10.3389/fcvm.2019.00054

50. Xiao GQ, Hu K, Boutjdir M. Direct inhibition of expressed cardiac l- and t-type calcium channels by igg from mothers whose children have congenital heart block. Circulation. (2001) 103:1599-604. doi: 10.1161/01.CIR.103.11.1599

51. Xiao GQ, Qu Y, Hu K, Boutjdir M. Down-regulation of L-type calcium channel in pups born to $52 \mathrm{kDa}$ SSA/Ro immunized rabbits. FASEB J. (2001) 15:1539-45. doi: 10.1096/fj.01-0052com

52. Karnabi E, Qu Y, Wadgaonkar R, Mancarella S, Yue Y, Chahine M, et al. Congenital heart block: identification of autoantibody binding site on the extracellular loop (domain I, S5-S6) of alpha(1D) L-type Ca channel. J Autoimmun. (2010) 34:80-6. doi: 10.1016/j.jaut.2009.06.005

53. Strandberg LS, Cui X, Rath A, Liu J, Silverman ED, Liu X, et al. Congenital heart block maternal sera autoantibodies target an extracellular epitope on the $\alpha 1 \mathrm{G}$ T-type calcium channel in human fetal hearts. PLoS ONE. (2013) 8:e72668. doi: 10.1371/journal.pone.0072668

54. Salomonsson S, Sonesson SE, Ottosson L, Muhallab S, Olsson T, Sunnerhagen M, et al. Ro/SSA autoantibodies directly bind cardiomyocytes, disturb calcium homeostasis, and mediate congenital heart block. J Exp Med. (2005) 201:11-7. doi: 10.1084/jem.20041859

55. Lee AYS. A review of the role and clinical utility of anti-Ro52/TRIM21 in systemic autoimmunity. Rheumatol Int. (2017) 37:1323-33. doi: $10.1007 / \mathrm{s} 00296-017-3718-1$

56. Damoiseaux J, Boesten K, Giesen J, Austen J, Tervaert JW. Evaluation of a novel line-blot immunoassay for the detection of antibodies to extractable nuclear antigens. Ann N Y Acad Sci. (2005) 1050:340-7. doi: 10.1196/annals.1313.036

57. Buyon JP, Winchester RJ, Slade SG, Arnett F, Copel J, Friedman D, et al. Identification of mothers at risk for congenital heart block and other neonatal lupus syndromes in their children. Comparison of enzymelinked immunosorbent assay and immunoblot for measurement of antiSS-A/Ro and anti-SS-B/La antibodies. Arthritis Rheum. (1993) 36:1263-73. doi: 10.1002/art.1780360911

58. Gordon PA, Khamashta MA, Hughes GR, Rosenthal E. Increase in the heart rate-corrected QT interval in children of anti-Ro-positive mothers, with a further increase in those with siblings with congenital heart block: comment on the article by Cimaz et al. Arthritis Rheum. (2001) 44:242-3. doi: 10.1002/1529-0131(200101)44:1 < 242::AID-ANR34>3.0.CO;2-S 
59. Cimaz R, Meroni PL, Brucato A, Fesstovà V, Panzeri P, Goulene K, et al. Concomitant disappearance of electrocardiographic abnormalities and of acquired maternal autoantibodies during the first year of life in infants who had QT interval prolongation and anti-SSA/Ro positivity without congenital heart block at birth. Arthritis Rheum. (2003) 48:266-8. doi: 10.1002/art.10700

60. Jaeggi E, Laskin C, Hamilton R, Kingdom J, Silverman E. The importance of the level of maternal anti-Ro/SSA antibodies as a prognostic marker of the development of cardiac neonatal lupus erythematosus a prospective study of 186 antibody-exposed fetuses and infants. J Am Coll Cardiol. (2010) 55:2778-84. doi: 10.1016/j.jacc.2010.02.042

61. AlTwajery M, AlMane W, Al-Mayouf SM. Electrocardiographic disturbances in children with systemic lupus erythematosus. Int J Pediatr Adolesc Med. (2018) 5:127-30. doi: 10.1016/j.ijpam.2018.12.002

62. Friedman DM, Kim M, Costedoat-Chalumeau N, Clancy R, Copel J, Phoon CK, et al. Electrocardiographic QT intervals in infants exposed to hydroxychloroquine throughout gestation. Circ Arrhythm Electrophysiol. (2020) 13:e008686. doi: 10.1161/CIRCEP.120.008686

63. Duke C, Stuart G, Simpson JM. Ventricular tachycardia secondary to prolongation of the QT interval in a fetus with autoimmune mediated congenital complete heart block. Cardiol Young. (2005) 15:319-21. doi: 10.1017/S1047951105000673

64. Wang B, Hu S, Shi D, Bing Z, Li Z. Arrhythmia and/or cardiomyopathy related to maternal autoantibodies: descriptive analysis of a series of 16 cases from a single center. Front Pediatr. (2019) 7:465. doi: 10.3389/fped.2019.00465

65. Mizuno M, Masumori C, Sakurai K, Nakano M, Aso K. Anti-Ro/SSA antibody-related atrioventricular block-induced torsade de pointes. Pediatr Int. (2020) 62:1101-3. doi: 10.1111/ped.14232

66. Lazzerini PE, Capecchi PL, Acampa M, Morozzi G, Bellisai F, Bacarelli $\mathrm{MR}$, et al. Anti-Ro/SSA-associated corrected QT interval prolongation in adults: the role of antibody level and specificity. Arthritis Care Res. (2011) 63:1463-70. doi: 10.1002/acr.20540

67. Pisoni CN, Reina S, Arakaki D, Eimon A, Carrizo C, Borda E. Elevated IL$1 \beta$ levels in anti-Ro/SSA connective tissue diseases patients with prolonged corrected QTc interval. Clin Exp Rheumatol. (2015) 33:715-20.

68. Sham S, Madheshwaran M, Tamilselvam T, Rajeswari S. Correlation of QT interval with disease activity in newly detected SLE patients at baseline and during flare. Indian J Rheumatol. (2015) 10:121-4. doi: 10.1016/j.injr.2015.03.010

69. Perez-Garcia L, Estevez-Garcia I, Ramirez MM, Felix JL, Marquez-Velasco R, Iturralde P, et al. Anti-Ro52/TRIM21 antibodies are associated with QT interval prolongation in patients with systemic lupus erythematosu [Abstract]. Arthritis Rheumatol. (2016) 68.

70. Tufan AN, Sag S, Oksuz MF, Ermurat S, Coskun BN, Gullulu $\mathrm{M}$, et al. Prolonged Tpeak-Tend interval in anti-Ro52 antibodypositive connective tissue diseases. Rheumatol Int. (2017) 37:67-73. doi: 10.1007/s00296-016-3488-1

71. Mostafavi A, Taassoarian B, Khadir V, Abbaszadeh S, Sanatkar S, Rafiei M. Assessment of the relationship between dose and number of effective used drugs on QT interval in patients with lupus. Shiraz E-Med J. (2020) 21:e83710. doi: 10.5812/semj.83710

72. Hu Z, Wu L, Lin Z, Liu X, Zhao C, Wu Z. Prevalence and associated factors of Electrocardiogram abnormalities in patients with systemic lupus erythematosus: a machine learning study. Arthritis Care Res. (2021). doi: 10.1002/acr.24612

73. Sánchez-Chapula JA, Salinas-Stefanon E, Torres-Jácome J, BenavidesHaro DE, Navarro-Polanco RA. Blockade of currents by the antimalarial drug chloroquine in feline ventricular myocytes. J Pharmacol Exp Ther. (2001) 297:437-45.

74. Traebert M, Dumotier B, Meister L, Hoffmann P, Dominguez-Estevez $\mathrm{M}$, Suter W. Inhibition of hERG $\mathrm{K}+$ currents by antimalarial drugs in stably transfected HEK293 cells. Eur J Pharmacol. (2004) 484:41-8. doi: 10.1016/j.ejphar.2003.11.003

75. Szendrey M, Guo J, Li W, Yang T, Zhang S. COVID-19 drugs chloroquine and hydroxychloroquine, but not azithromycin and Remdesivir, Block hERG Potassium Channels. J Pharmacol Exp Ther. (2021) 377:265-72. doi: 10.1124 /jpet.120.000484
76. Nishiyama T, Kondo Y, Tsuboi H, Noma H, Tabuchi D, Sugita $\mathrm{T}$, et al. QTc interval prolongation in patients with systemic lupus erythematosus treated with hydroxychloroquine. Mod Rheumatol. 2021:110. doi: 10.1080/14397595.2021.1879368

77. Gordon PA, Rosenthal E, Khamashta MA, Hughes GR. Absence of conduction defects in the electrocardiograms [correction of echocardiograms] of mothers with children with congenital complete heart block. J Rheumatol. (2001) 28:366-9.

78. Motta M, Rodriguez-Perez C, Tincani A, Lojacono A, Chirico G. Outcome of infants from mothers with anti-SSA/Ro antibodies. J Perinatol. (2007) 27:278-83. doi: 10.1038/sj.jp.7211688

79. Nomura A, Kishimoto M, Takahashi O, Deshpande GA, Yamaguchi K, Okada M. Prolongation of heart rate-corrected QT interval is a predictor of cardiac autonomic dysfunction in patients with systemic lupus erythematosus. Rheumatol Int. (2014) 34:643-7. doi: 10.1007/s00296-013-2718-z

80. Bourré-Tessier J, Urowitz MB, Clarke AE, Bernatsky S, Krantz MJ, Huynh $\mathrm{T}$, et al. Electrocardiographic findings in systemic lupus erythematosus: data from an international inception cohort. Arthritis Care Res. (2015) 67:128-35. doi: 10.1002/acr.22370

81. Costedoat-Chalumeau N, Amoura Z, Lupoglazoff JM, Huong DL, Denjoy I, Vauthier D, et al. Outcome of pregnancies in patients with antiSSA/Ro antibodies: a study of 165 pregnancies, with special focus on electrocardiographic variations in the children and comparison with a control group. Arthritis Rheum. (2004) 50:3187-94. doi: 10.1002/art.20554

82. Gerosa M, Cimaz R, Stramba-Badiale M, Goulene K, Meregalli E, Trespidi $\mathrm{L}$, et al. Electrocardiographic abnormalities in infants born from mothers with autoimmune diseases-a multicentre prospective study. Rheumatology. (2007) 46:1285-9. doi: 10.1093/rheumatology/kem073

83. Teixeira RA, Borba EF, Pedrosa A, Nishioka S, Viana VS, Ramires JA, et al. Evidence for cardiac safety and antiarrhythmic potential of chloroquine in systemic lupus erythematosus. Europace. (2014) 16:887-92. doi: 10.1093/europace/eut 290

84. Costedoat-Chalumeau N, Amoura Z, Hulot JS, Ghillani P, Lechat P, FunckBrentano C, et al. Corrected QT interval in anti-SSA-positive adults with connective tissue disease: comment on the article by Lazzerini et al. Arthritis Rheum. (2005) 52:676-7. doi: 10.1002/art.20845

85. Massie C, Hudson M, Tatibouet S, Steele R, Huynh T, Fritzler MJ, et al. Absence of an association between anti-Ro antibodies and prolonged QTc interval in systemic sclerosis: a multicenter study of 689 patients. Semin Arthritis Rheum. (2014) 44:338-44. doi: 10.1016/j.semarthrit.2014.07.001

86. Geraldino-Pardilla L, Gartshteyn Y, Piña P, Cerrone M, Giles JT, Zartoshti A, et al. ECG non-specific ST-T and QTc abnormalities in patients with systemic lupus erythematosus compared with rheumatoid arthritis. Lupus Sci Med. (2016) 3:e000168. doi: 10.1136/lupus-2016-000168

87. Azharudeen M, Thabah MM, Satheesh S, Negi VS. QT interval parameters, anti-Ro antibody status, and disease activity in systemic lupus erythematosus. J $R$ Coll Physicians Edinb. (2020) 50:380-6. doi: 10.4997/JRCPE.2020.406

88. Dugar M, Cox S, Limaye V, Gordon TP, Roberts-Thomson PJ. Diagnostic utility of anti-Ro52 detection in systemic autoimmunity. Postgrad Med J. (2010) 86:79-82. doi: 10.1136/pgmj.2009.089656

89. Lazzerini PE, Capecchi PL, Boutjdir M, Laghi-Pasini F. Comment on "absence of an association between anti-Ro antibodies and prolonged QTc interval in systemic sclerosis: a multicenter study of 689 patients". Semin Arthritis Rheum. (2015) 44:e16-7. doi: 10.1016/j.semarthrit.2014.10.002

90. Lazzerini PE, Capecchi PL, Laghi-Pasini F. Assessing QT interval in patients with autoimmune chronic inflammatory diseases: perils and pitfalls. Lupus Sci Med. (2016) 3:e000189. doi: 10.1136/lupus-2016-000189

91. Lazzerini PE, Capecchi PL, El-Sherif N, Laghi-Pasini F, Boutjdir M. Emerging arrhythmic risk of autoimmune and inflammatory cardiac channelopathies. J Am Heart Assoc. (2018) 7:e010595. doi: 10.1161/JAHA.118.010595

92. Roden DM. Repolarization reserve: a moving target. Circulation. (2008) 118:981-2. doi: 10.1161/CIRCULATIONAHA.108.798918

93. Arteyeva NV, Goshka SL, Sedova KA, Bernikova OG, Azarov JE. What does the T(peak)-T(end) interval reflect? An experimental and model study. J Electrocardiol. (2013) 46:296.e1-8. doi: 10.1016/j.jelectrocard.2013.02.001 
94. Priori SG, Wilde AA, Horie M, Cho Y, Behr ER, Berul C, et al. HRS/EHRA/APHRS expert consensus statement on the diagnosis and management of patients with inherited primary arrhythmia syndromes: document endorsed by HRS, EHRA, and APHRS in May 2013 and by ACCF, AHA, PACES, and AEPC in June (2013). Heart Rhythm. (2013) 10:1932-63. doi: 10.1016/j.hrthm.2013.05.014

95. Yang P, Kanki H, Drolet B, Yang T, Wei J, Viswanathan PC, et al. Allelic variants in long-QT disease genes in patients with drugassociated torsades de pointes. Circulation. (2002) 105:1943-8. doi: 10.1161/01.CIR.0000014448.19052.4C

96. Kääb S, Crawford DC, Sinner MF, Behr ER, Kannankeril PJ, Wilde $\mathrm{AA}$, et al. A large candidate gene survey identifies the KCNE1 D85N polymorphism as a possible modulator of drug-induced torsades de pointes. Circ Cardiovasc Genet. (2012) 5:91-9. doi: 10.1161/CIRCGENETICS.111. 960930

97. Itoh H, Crotti L, Aiba T, Spazzolini C, Denjoy I, Fressart V, et al. The genetics underlying acquired long QT syndrome: impact for genetic screening. Eur Heart J. (2016). 37:1456-64. doi: 10.1093/eurheartj/ehv695

98. Lazzerini PE, Laghi-Pasini F, Bertolozzi I, Morozzi G, Lorenzini S, Simpatico A, et al. Systemic inflammation as a novel QT-prolonging risk factor in patients with torsades de pointes. Heart. (2017) 103:1821-9. doi: 10.1136/heartjnl-2016-311079

99. Lazzerini PE, Bertolozzi I, Finizola F, Acampa M, Natale M, Vanni F, et al. Proton pump inhibitors and serum magnesium levels in patients with Torsades de Pointes. Front Pharmacol. (2018) 9:363. doi: 10.3389/fphar.2018.00363

100. Sammaritano LR, Bermas BL, Chakravarty EE, Chambers C, Clowse MEB, Lockshin MD, et al. American College of rheumatology guideline for the management of reproductive health in rheumatic and musculoskeletal diseases. Arthritis Rheumatol. (2020) 72:529-56. doi: 10.1002/art. 41191

101. Lazzerini PE, Capecchi PL, Laghi-Pasini F. Isolated atrioventricular block of unknown origin in adults and anti-Ro/SSA antibodies: clinical evidence, putative mechanisms, and therapeutic implications. Heart Rhythm. (2015) 12:449-54. doi: 10.1016/j.hrthm.2014. 10.031
102. Santos-Pardo I, Martínez-Morillo M, Villuendas R, Bayes-Genis A. AntiRo antibodies and reversible atrioventricular block. N Engl J Med. (2013) 368:2335-7. doi: 10.1056/NEJMc1300484

103. Lazzerini PE, Brucato A, Capecchi PL, Baldi L, Bacarelli MR, Nucci C, et al. Isolated atrioventricular block of unknown origin in the adult and autoimmunity: diagnostic and therapeutic considerations exemplified by 3 anti-Ro/SSA-associated cases. Heart Rhythm Case Rep. (2015) 1:293-9. doi: 10.1016/j.hrcr.2015.03.019

104. Saribayev M, Tufan F, Oz F, Erer B, Ozpolat T, Ozturk GB, et al. Corticosteroid treatment normalizes QTc prolongation and improves heart block in an elderly patient with anti-Ro-positive systemic lupus erythematosus. Aging Clin Exp Res. (2014) 26:337-9. doi: 10.1007/s40520-013-0168-9

105. Soukup T, Toms J, Pudil R, Simka J, Pollak L, Jurikova N, et al. AB0485 Intravenous high dose glucocorticoids cause prolongation of QT interval in connective tissue disease patients except anti-Ro positive subgroup. Ann Rheum Dis. (2019) 78:1706. doi: 10.1136/annrheumdis-2019-eular.4253

Conflict of Interest: The authors declare that the research was conducted in the absence of any commercial or financial relationships that could be construed as a potential conflict of interest.

Publisher's Note: All claims expressed in this article are solely those of the authors and do not necessarily represent those of their affiliated organizations, or those of the publisher, the editors and the reviewers. Any product that may be evaluated in this article, or claim that may be made by its manufacturer, is not guaranteed or endorsed by the publisher.

Copyright (๑) 2021 Lazzerini, Laghi-Pasini, Boutjdir and Capecchi. This is an openaccess article distributed under the terms of the Creative Commons Attribution License (CC BY). The use, distribution or reproduction in other forums is permitted, provided the original author(s) and the copyright owner(s) are credited and that the original publication in this journal is cited, in accordance with accepted academic practice. No use, distribution or reproduction is permitted which does not comply with these terms. 